\title{
Influence of processing conditions on rheological properties of aqueous extract chia (Salvia hispanica L.) mucilage
}

\author{
1,2* Hussain, N., ${ }^{1,3}$ Ishak, I., ${ }^{2}$ Sulaiman, R., ${ }^{2}$ Fauzi, N.M. and ${ }^{4}$ Coorey, R. \\ ${ }^{1}$ Halal Products Research Institute, 43400 Universiti Putra Malaysia, Selangor, Malaysia \\ ${ }^{2}$ Department of Food Technology, Faculty of Food Science and Technology, Universiti Putra Malaysia, \\ 43400 UPM Serdang, Selangor, Malaysia \\ ${ }^{3}$ Innovation Centre for Confectionery Technology (MANIS), Faculty of Science and Technology, Universiti \\ Kebangsaan Malaysia, 43600 Bangi, Selangor, Malaysia \\ ${ }^{4}$ School of Molecular and Life Sciences, Curtin University, Perth, Western Australia, Australia
}

\section{Article history:}

Received: 10 July 2019

Received in revised form: 27

October 2019

Accepted: 31 October 2019

Available Online: 10

February 2020

\section{Keywords:}

Chia seed,

Chia mucilage,

Aqueous extract,

Thickener,

Viscosity,

Rheological properties

DOI:

https://doi.org/10.26656/fr.2017.4(S1).S03

\section{Abstract}

The purpose of this study was to determine the effects of soaking temperature $\left(25\right.$ and $80^{\circ}$ C) and different processing conditions on the rheological properties of chia seeds (Salvia hispanica L.) mucilage. In this study, chia mucilage was first extracted using a ratio of seed to water at $1: 10$ for $4 \mathrm{hrs}$ for control $\left(25^{\circ} \mathrm{C}\right)$ and treated mucilage $\left(80^{\circ} \mathrm{C}\right)$. Both extracted mucilage were evaluated in terms of yield, color, solubility, and water holding capacity. Then, the mucilage were subjected to different processing conditions including temperatures $\left(5,25,45\right.$, and $\left.65^{\circ} \mathrm{C}\right), \mathrm{pH}(3,5,7,9)$, sucrose concentrations $(10,20,30$, $40 \%$ ), and salts ( $\mathrm{NaCl}$ and $\mathrm{KCl}$ from 0 to $0.172 \mathrm{M} ; \mathrm{CaCl}_{2}$ and $\mathrm{MgCl}_{2}$ from 0 to $0.049 \mathrm{M}$ ) to determine their rheological properties. Results show that high extraction temperature $\left(80^{\circ} \mathrm{C}\right)$ significantly affected the mucilage yield higher than control. However, lightness $\left(L^{*}\right)$, solubility and water holding capacity of the treated sample were lower compared to control. Apparent viscosity of the $3 \%$ of mucilage for both extracts increases with temperatures and sucrose concentration. The high apparent viscosity of the treated mucilage at $\mathrm{MgCl}_{2}(0.049 \mathrm{M})$ and $\mathrm{CaCl}_{2}(0.049 \mathrm{M})$ concentration were found higher than $0.01 \mathrm{M}$. Meanwhile, $\mathrm{NaCl}(>0.069 \mathrm{M}), \mathrm{KCl}(>0.035 \mathrm{M})$, and $\mathrm{CaCl}_{2}(<0.03 \mathrm{M})$ had decreased the apparent viscosity value of the control sample. Thus, the treated mucilage could be suitable for application as a thickening agent in food.

\section{Introduction}

Chia (Salvia hispanica L.) seed is an annual herb that belongs to Lamiaceae family, which is widely consumed in Mexico, Argentina, and Southwestern United States (Segura-Campos et al., 2014). Chia seeds have high oil content (30-40\%) which is rich in linolenic acid (54-67\%) and linoleic acid (12-21\%) (Ixtaina et al., 2011). Nevertheless, chia seed could prevent cardiovascular disease and cancer as it contains natural antioxidants such as phenolic glycoside-Q and $K$, quercetin and kaempferol which have cardiac protective effects and anti-carcinogenic characteristics (ReyesCaudillo et al., 2008). Chia seed is also high in quality proteins (19-27\%) with the right balance of essential amino acids, especially methionine and cysteine (Ayerza, 2013).

Previous study reported that high fibre content in chia seed mucilage contributes to the potential source of polysaccharide gums which can be added at low concentration in aqueous solutions (Hulse, 1996). Chia mucilage has been used as a substitute for egg and oil in the cake formulations and development of mayonnaise which improves the stability and texture of the products (Borneo et al., 2010). Usually, chia mucilage is used as a food thickener similar to hydrocolloids, which include pectin, gum Arabic and cellulose. Chia mucilage is recommended for industrial use due to its slimy properties and dietary fibre content (Segura-Campos et al., 2014).

Nowadays, the addition of chia mucilage in food products is widely used in many food industries. Chia mucilage has been used as a replacer for stabilizers and emulsifiers in the ice cream preparations (Campos et al., 2016). Chia mucilage also contributes to the reduction of the fat content by $50 \%$ in bread and chocolate cakes, which result in healthier products and preserved quality attributes (Fernandes and de las Mercedes Salas- 
Mellado, 2017). Other than that, it has also been added into the rice flour gluten-free pasta to improve the nutritional profile and act as a thickening agent (Menga et al., 2017).

Chia seeds mucilage can be extracted using several types of methods such as cold extraction using freeze drier at $-50^{\circ} \mathrm{C}$ with different ratio of seed to water $(1: 10$ $1: 40)$. It was found that high mucilage yield produced at a ratio of seed to water of 1:10 (Muñoz et al., 2012). There was also an extraction of mucilage Lepidium sativum seed using solvents (alcohol and acetone) with a better yield, but not cost-effective (Kilor and Bramhe, 2014). Mucilage of chia seed is a complex high molecular weight polysaccharide extracted when the seeds come into contact with water; thus, it will increase the solution viscosity (Lin et al., 1994). Chia seeds convey a similar characteristic to flax and basil seed, which discharge a clear mucilaginous gel when it is soaked in water at a ratio of 1:65 (Hosseini-Parvar et al., 2010). Chia mucilage can also be extracted by hydration of chia seed with water at a ratio of $1: 20$ and 1:40 (Muñoz et al., 2012).

Previous study by Campos et al. (2016) studied the effect of extraction temperature $\left(30\right.$ to $\left.80^{\circ} \mathrm{C}\right)$, extraction time ( 2 to $4 \mathrm{hrs}$ ) and water to seed ratio (1:30) on the yield and apparent viscosity of chia mucilage. It is stated that the optimum parameters for the extraction of chia mucilage were at $80^{\circ} \mathrm{C}, 4 \mathrm{hrs}$ extraction with water to seed ratio of 1:30 to produce a higher yield of mucilage (4.95\%). However, none has studied on the effect of soaking the seeds at room temperature on the yield and characteristics of the mucilage produced. Moreover, chia mucilage has rheological properties including thickening capacity (Capitani et al., 2013), adhesion and as a component for biodegradable films to increase the shelf life of foods. The rheological analysis is aimed to determine the viscoelastic behavior of hydrocolloids in the solution (chia mucilage) which could be affected by different variables such as shear rate, time, $\mathrm{pH}$ and temperature (Capitani et al., 2015). Apart from that, there were also study conducted on the effect of different temperatures $\left(5,25,45\right.$ and $\left.65^{\circ} \mathrm{C}\right), \mathrm{pH}$ (3 to 9), salt $(0.035$ to $0.172 \%)$ on final concentration of monovalent ( $\mathrm{NaCl}$ and $\mathrm{KCl})$ while $(0.01$ to $0.049 \%)$ concentration of divalent $\left(\mathrm{CaCl}_{2}\right.$ and $\left.\mathrm{MgCl}_{2}\right)$ and sugar at concentration in the range of 0 to $40 \%$ of rheological properties of mucilage extracted from Alyssum homolocarpum seed (Koocheki et al., 2009). This finding showed a decrease in viscosity due to low temperature, low $\mathrm{pH}$ (ReyesCaudillo et al., 2008), a high concentration of salt and sucrose. However, none has studied on the effect of the above processing conditions (temperature, $\mathrm{pH}$, salts and sugar concentration) on properties of the chia mucilage.
Thus, the objectives of this study were to determine the effect of soaking temperature $\left(25\right.$ and $\left.80^{\circ} \mathrm{C}\right)$ on yield, color, solubility, and water holding capacity of aqueous chia seed mucilage (Salvia hispanica L.). The final objective was to determine the effects of different processing conditions, which were temperature, $\mathrm{pH}$, salts and sucrose concentration on the rheological properties of chia mucilage.

\section{Materials and methods}

\subsection{Materials}

The chia (Salvia hispanica L.) seed (black) was supplied by The Chia Company (Victoria, Australia). Meanwhile, all solvents involved in the proximate analysis were purchased from Sigma-Aldrich, United States.

\subsection{Proximate analysis}

The proximate analysis was carried out for raw chia seeds to determine moisture, ash contents, crude protein, fat and fibre using standard methods of Analytical Chemist methods: 934.01, 942.05, 992.15, 954.02, 978.10 (AOAC, 2000), respectively.

\subsection{Extraction of mucilage}

The extraction of chia seeds mucilage was done by soaking the seeds in distilled water with seed to water ratio of 1:10 (Campos et al., 2016). The solutions were agitated continuously using water bath shaker (Protech, Malaysia) and heated at a temperature of $80^{\circ} \mathrm{C}$ for $4 \mathrm{hrs}$ (Campos et al., 2016). A control sample was prepared using a similar seed to water ratio $(1: 10)$ and agitated continuously using a water bath shaker (Protech, Malaysia) at room temperature for $4 \mathrm{hrs}$.

The extraction method used in this study was selected based on preliminary research using different ratio of seed to water $(1: 10$ to $1: 30)$ at $80^{\circ} \mathrm{C}$ for $4 \mathrm{hrs}$. It shows that a higher yield of chia mucilage obtained at the water to seed ratio of $1: 10$, which contributed to higher viscosity of mucilage.

Then, both solutions containing mucilage at sufficient amount were blended once it reached room temperature $\left(25^{\circ} \mathrm{C}\right)$ until it turns milky white using a wet blender (Panasonic Blender MX-GM1011, Malaysia). Then, the mucilage solution formed was separated using a centrifuge (Kubota 3740 Model, Japan) at $3500 \mathrm{rpm}$ for 75 mins (Dick et al., 2015). The samples formed three separate layers, which consist of seed coats at the bottom layer, mucilage (middle layer), and water on the top. The water was discarded out, and the mucilage was scraped out using spatula manually. 


\subsection{Yield of extraction}

The extraction yield (\%) of chia (Salvia hispanica L.) mucilage was determined with a slight modification by changing the form of a sample from mucilage powder to liquid form (Zeng and Lai, 2014).

\subsection{Instrumental colour measurement}

The colour parameters $\left(L^{*}, a^{*}, b^{*}\right)$, of the mucilage, were determined using a chromameter (CR-400, Konica Minolta Sensing Inc., Japan) which represents white to black, red to green, and yellow to blue respectively (Timilsena et al., 2015).

\subsection{Solubility}

Solubility (\%) of the extracted mucilage followed Zeng and Lai (2014). Firstly, $50 \mathrm{mg}$ of chia mucilage (W) was mixed with $10 \mathrm{~mL}$ of deionised water and stirred using magnetic stirrer with $250 \mathrm{rpm}$ at room temperature for $24 \mathrm{hrs}$. Then, after centrifuging the sample solution $(6000 \times \mathrm{g})$ for $15 \mathrm{mins}$, the supernatant was poured out and the $15 \mathrm{~mL}$ (W1) containing precipitant of mucilage was dried at $105^{\circ} \mathrm{C}$ till it reached constant weight (W2). The solubility of the mucilage was calculated according to the following equation:

$$
\text { Solubility }(\%)=\frac{W+W 1+W 2}{W} \times 100
$$

\subsection{Water-Holding Capacity (WHC)}

The water holding capacity was determined according to the method by Norlaila et al. (2015). One gram of chia mucilage was added into $10 \mathrm{~mL}$ of distilled water. Then, the mixture was vortexed using Vortex mixer (VTX-3000L, Japan) for 2 mins and centrifuged at $3000 \mathrm{rpm}$ for $30 \mathrm{mins}$ before poured out the supernatant. The WHC is calculated by dividing the weight $(\mathrm{g})$ of water absorbed by $100 \mathrm{~g}$ of chia mucilage.

\subsection{Rheological measurement}

\subsubsection{Preparation of solutions}

The preparation of mucilage solution was done following method by Koocheki et al. (2009). The mucilage solutions were prepared at concentrations of $3 \%$ by adding $3 \mathrm{~g}$ of mucilage in $100 \mathrm{~mL}$ of distilled water and stirred manually at room temperature (Koocheki et al., 2009). The 3\% of chia mucilage was chosen based on the study conducted by Koocheki et al. (2009) where the concentration of Alyssum homolocarpum seed showed good rheological behaviors (flow properties and viscosity) on different processing conditions ( $\mathrm{pH}$, salt and sugar concentrations).

\subsubsection{Apparent viscosity}

The apparent viscosity was done according to the method by Koocheki et al. (2009) with slight modification using a rheometer with $60 \mathrm{~mm}$ discs probe and a heating circulator. For each test, approximately 2 to $3 \mathrm{~mL}$ of the sample was transferred to $60 \mathrm{~mm}$ of disc following by 2 mins pre-shearing at $100 \mathrm{~s}^{-1}$ to obtain a uniform solution. The instrument was set to $25^{\circ} \mathrm{C}$ and equilibrated for 10 mins followed by two-cycle shear in which the shear rate was increased linearly from 0 to 300 $\mathrm{s}^{-1}$ in 3 mins and immediately decreased to $0 \mathrm{~s}^{-1}$ in the next 3 mins. The flow behavior index $(n)$ and consistency index $(k)$ value computed by fitting the power law model, using the following equation:

$$
\tau=k \gamma^{n}
$$

Where $\tau$ is the shear stress $(\mathrm{Pa}),\left(\gamma^{*}\right)$ is the shear rate $\left(\mathrm{s}^{-1}\right), k$ is the consistency coefficients $\left(\mathrm{Pa} \mathrm{s}{ }^{n}\right)$, and $n$ is the flow behavior index (dimensionless)

Effects of different processing conditions $(\mathrm{pH}$, temperature, salts, and sucrose) on chia mucilage samples were analyzed using a similar methodology above.

\subsubsection{Determination of flow properties at different sugar concentrations}

Sugar was dissolved in $100 \mathrm{~mL}$ of water to obtain $0 \%, 10 \%, 20 \%, 30 \%$, and $40 \%$ of sugar concentration, then added into $3 \%$ of mucilage solutions. The flow behavior index $(n)$ and consistency index $(k)$ values were measured at $25^{\circ} \mathrm{C}$ (Koocheki et al., 2009).

\subsubsection{Effects of different $p H$ on mucilage flow properties}

A $3 \%$ of chia mucilage solution was adjusted to $\mathrm{pH}$ $3.0,5.0,7.0$, and 9.0 by adding either $0.1 \mathrm{~mol} / \mathrm{L} \mathrm{NaOH}$ or $\mathrm{HCl}$. The viscosity and flow properties were tested at a constant temperature of $25^{\circ} \mathrm{C}$ (Koocheki et al., 2009).

\subsubsection{Effects of different temperatures (5, 25, 45 and $80^{\circ} \mathrm{C}$ ) on mucilage viscosity}

A $3 \%$ of chia mucilage solution was poured on to the rheometer discs probe and analysed for $10 \mathrm{mins}$ at different temperatures of $5,25,45$ or $65^{\circ} \mathrm{C}$. The temperature dependence of consistency coefficient (the indicator of the viscous nature of the sample) assessed by fitting the Arrhenius model (Sengül et al., 2005), using the following equation:

$$
\mathrm{k}=k_{0} \cdot \mathrm{e}(\mathrm{Ea} / \mathrm{RT})
$$

Where $k_{0}$ is proportionality constant (or consistency coefficient at a reference temperature, $\left.\mathrm{Pa} \mathrm{s}^{\mathrm{n}}\right), \mathrm{E}_{\mathrm{a}}$ refers to activation energy $(\mathrm{J} / \mathrm{mol}), \mathrm{R}$ is universal law gas constant $(\mathrm{J} / \mathrm{mol} \mathrm{K})$, and $\mathrm{T}$ is absolute temperature $\left({ }^{\circ} \mathrm{K}\right)$. 
2.8.6 Effects of different salt concentration on mucilage viscosity

A $3 \%$ of chia mucilage solution was tested with monovalent $(\mathrm{NaCl}$ and $\mathrm{KCl})$ and divalent $\left(\mathrm{CaCl}_{2}\right.$ and $\mathrm{MgCl}_{2}$ ) salts where the salts were added to obtain final concentrations of $\mathrm{NaCl}$ and $\mathrm{KCl}(0.035,0.069,0.103$, 0.138 and $0.172 \mathrm{M}$ ) while, $\mathrm{CaCl}_{2}$ and $\mathrm{MgCl}_{2}(0.01,0.02$, $0.03,0.03$ and $0.049 \mathrm{M})$, respectively. Viscosity measurements were performed at a temperature of $25^{\circ} \mathrm{C}$. Different types of salt were important to determine the mucilage behaves as a polyelectrolyte and to estimate the functional rheological properties (Koocheki et al., 2009).

\subsection{Statistical analysis}

Analysed samples were taken in triplicate. All the data were analysed using one-way ANOVA in Minitab software. All values were expressed as a mean \pm standard deviation to identify the significant difference among the samples under a confidence interval of $95 \%$.

\section{Results and discussion}

The composition of chia seed, as shown in Table 1 conveys that chia seeds are high fibre and protein content. The fibre and protein content observed in this study were slightly higher than the nutritional composition, which has been reported by the National Nutrient Database for Standard Reference (USDA, 2011). The high fibre content of chia seed promotes the feeling of fullness and prevents the increase of blood sugar after eating a meal (de Souza et al., 2015).The different origin and environment conditions of chia seeds contribute to the variations in protein content of chia seeds obtained from Mexico with the range of 18.5 to $22.3 \%$ (Porras-Loaiza et al., 2014) while in this study, the protein content of chia seed from Australia contains $26.87 \%$.

Table 1. Composition of raw chia seed

\begin{tabular}{lcc}
\hline \multicolumn{1}{c}{ Type of analysis } & Chia seed (\%) & USDA (\%) \\
\hline Ash & $4.78 \pm 0.07$ & - \\
Moisture & $4.85 \pm 0.05$ & - \\
Fat & $7.70 \pm 0.08$ & 30.74 \\
Protein & $26.87 \pm 0.08$ & 16.54 \\
Fibre & $35.80 \pm 0.06$ & 34.4 \\
Carbohydrate & $21.10 \pm 0.00$ & 42.12 \\
\hline
\end{tabular}

Table 2 shows the yield and color properties of control and treated samples. There is a significant difference $(p<0.05)$ between the mucilage yield of control $\left(25^{\circ} \mathrm{C}\right)$ and treated sample $\left(80^{\circ} \mathrm{C}\right)$. The result indicated that the extraction of chia mucilage by soaking the seedsat high temperature $\left(80^{\circ} \mathrm{C}\right)$ gave an effect on the yield of mucilage. This result was similar to the previous study (Muñoz et al., 2012), which had carried out the extraction of chia mucilage using the soaking method at $80^{\circ} \mathrm{C}$. The study reported that extraction of mucilage at a temperature of $80^{\circ} \mathrm{C}$ could give high percentage yield, (53.60\%) compared to the extraction at low temperature $\left(20^{\circ} \mathrm{C}\right)$ at the ratio of seed to water $(1: 40)$. Commonly, high temperature allows water to penetrate a solid matrix of seeds and cause the release of mucilage easily (Muñoz et al., 2012).The color of chia mucilage was presented in Table 2. There was a significant difference $(p<0.05)$ between $L^{*}, a^{*}, b^{*}$ value for control $\left(25^{\circ} \mathrm{C}\right)$ and treated sample $\left(80^{\circ} \mathrm{C}\right)$. In terms of lightness $\left(L^{*}\right)$ value, the treated sample has a significantly $(p<0.05)$ lower value (49.76 \pm 0.06$)$ compared to the control $(54.34 \pm 0.13)$. The treated mucilage formed a brownish color due to exposure of high temperature which caused by an enzymatic browning thus affecting the properties of polysaccharides (Qian et al., 2012) compared to the mucilage extracted at room temperature that has a brighter color.

Table 2. Yield and colour properties of control and treated samples

\begin{tabular}{ccccc}
\hline \multirow{2}{*}{$\begin{array}{c}\text { Type of } \\
\text { samples }\end{array}$} & Yield (\%) & \multicolumn{4}{c}{ Colour } \\
\cline { 2 - 5 } & & $\mathrm{L}$ & $\mathrm{a}$ & $\mathrm{b}$ \\
\hline Control & $50.88 \pm 0.46^{\mathrm{a}}$ & $54.34 \pm 0.13^{\mathrm{a}}$ & $2.36 \pm 0.03^{\mathrm{b}}$ & $9.57 \pm 0.18^{\mathrm{a}}$ \\
Treated & $53.60 \pm 0.30^{\mathrm{b}}$ & $49.76 \pm 0.06^{\mathrm{b}}$ & $2.89 \pm 0.02^{\mathrm{a}}$ & $9.90 \pm 0.06^{\mathrm{b}}$ \\
\hline
\end{tabular}

Different superscript letters in the same column indicates significant different at $(\mathrm{p}<0.05)$

Control $\left(25^{\circ} \mathrm{C}\right)$ and treated samples $\left(80^{\circ} \mathrm{C}\right)$ were measured for its solubility in water and water holding capacity (WHC). In this study, the mucilage was completely soluble in water at room temperature compared to high temperature. This study shows that the control was significantly more soluble in water $(60.52 \%)$ compared to chia mucilage extracted at high temperature $(60.01 \%)$ due to the complete dispersion of mucilage at room temperature followed by the water penetration into the mucilage (Doublier and Cuvelier, 2017). This result was similar to the solubility of Larch gum, which has a solubility value of $60 \%$ at room temperature. Heat applied during the mucilage extraction able to reduce viscosity and break mucilage cells to drive out mucilage. In addition, prolonged extraction time of mucilage ata higher temperature (more than $50^{\circ} \mathrm{C}$ ) may produce the insoluble components that caused the weakness of intermolecular interaction which retard solubility and water-binding capacity (WHC) of the mucilage. As a result, a decreased in the ability of mucilage to form dispersion in water (Korir et al., 2018). The degree of mucilage solubility was also influenced by the extraction conditions and the polysaccharide fraction that high in protein content presented in the chemical structure of 
chia mucilage (Amid et al., 2012).Other than that, WHC was measured to observe the ability of a substance to associate with water and hold water in producing gels or highly viscous solution (Korir et al., 2018). Based on the results in Table 3, it shows that the control has a higher value of water holding capacity compared to the treated sample with a significant difference. This could be due to high extraction temperature which affects the decrease of water holding capacity of mucilage (Koocheki et al., 2009). Moreover, a high value of WHC could be due to the presence of polysaccharide in chia mucilage that contributes to the greater affinity to absorb water (Noorlaila et al., 2015). It can be seen that mucilage extracted at room temperature had high capacity of holding water.

Table 3. Solubility and water holding capacity properties of control and treated samples

\begin{tabular}{ccc}
\hline Types of sample & Solubility (\%) & Water-Holding Capacity \\
\hline Control & $60.52 \pm 0.02^{\mathrm{a}}$ & $13.48 \pm 0.28^{\mathrm{a}}$ \\
Treated & $60.01 \pm 0.16^{\mathrm{b}}$ & $10.18 \pm 0.14^{\mathrm{b}}$ \\
\hline
\end{tabular}

Different superscript letters in the same column indicates significant different at $(\mathrm{p}<0.05)$

The apparent viscosity of control $\left(25^{\circ} \mathrm{C}\right)$ and extracted mucilage $\left(80^{\circ} \mathrm{C}\right)$ was studied to determine the effect of processing conditions such as the addition of different sucrose concentrations, $\mathrm{pH}$, temperatures and salts on chia mucilage as stated in Table 4 to 7 . The apparent viscosity was measured using a power law model to obtain the consistency coefficient $(k)$, and flow behavior index $(n)$ values. The flow behavior index $(n)$ indicates the degree of non-Newtonian characteristics of the fluid. As the fluid becomes more viscous, the consistency index $(k)$ increases and the flow behavior decreases. All data tabulated with the best values for the coefficient of determination, which was $\left(\mathrm{R}^{2}>0.9\right)$. Increase in apparent viscosity $(\mathrm{Pa} \cdot \mathrm{s})$ indicates that the substances are highly viscous. Chia mucilage exhibited pseudoplastic shear thinning behavior as the thickness decreased at increased in shear rate.

The apparent viscosity $(\mathrm{Pa} \cdot \mathrm{s})$ of different sucrose concentrations on the consistency coefficient $(k)$, and flow behavior index $(n)$ was stated in Table 4 . It shows that the increase in apparent viscosity of chia mucilage with an increase in the concentration of sucrose $(10,20$, 30 and $40 \%)$ for both control $\left(25^{\circ} \mathrm{C}\right)$ and treated chia seed $\left(80^{\circ} \mathrm{C}\right)$. Nevertheless, the apparent viscosity for the solutions added with sucrose is higher than a solution with the absence of sucrose in both samples. This result was similar to the rheological behavior study conducted on Alyssum homolocarpum seed gum (Koocheki et al., 2009). It was also supported by the previous research, which showed that the increase of apparent viscosity is due to the presence of $10 \%$ sugars (Behrouzian et al., 2013).The apparent viscosity of treated mucilage, as stated in Table 4 was higher $(8.9943 \mathrm{mPa} \cdot \mathrm{s})$ than control $(8.5395 \mathrm{mPa} \cdot \mathrm{s})$ at a concentration of $40 \%$. It shows that treated mucilage is more viscous than control as flow behavior index, $n$ decreased. The $k$ value also increased

Table 4. The Power law values of different types of mucilage at different sucrose concentrations

\begin{tabular}{|c|c|c|c|c|}
\hline Type of sample & Sucrose concentration $(\%)$ & $\eta_{\mathrm{a}, 100}(\mathrm{mPa} \cdot \mathrm{s})$ & $k\left(\right.$ Pa.s $\left.^{n}\right)$ & $n$ \\
\hline \multirow{4}{*}{ Control } & 10 & 8.3948 & 472.51 & 0.1248 \\
\hline & 20 & 8.4175 & 472.26 & 0.1255 \\
\hline & 30 & 8.7561 & 504.79 & 0.1196 \\
\hline & 40 & 8.5395 & 523.64 & 0.1062 \\
\hline \multirow{4}{*}{ Treated } & 10 & 8.3536 & 467.6 & 0.126 \\
\hline & 20 & 8.6943 & 493.69 & 0.1228 \\
\hline & 30 & 8.9355 & 528.59 & 0.114 \\
\hline & 40 & 8.9943 & 548.74 & 0.1073 \\
\hline \multicolumn{5}{|c|}{$\eta_{a, 100}$ indicates apparent viscosity; $\mathrm{k}$ is consistency index; $\mathrm{n}$ is flow behavior index; } \\
\hline \multicolumn{5}{|c|}{ Table 5. The Power law values of different types of mucilage at different $\mathrm{pH}$} \\
\hline Type of sample & $\mathrm{pH}$ & $\eta_{\mathrm{a}, 100}(\mathrm{mPa} \cdot \mathrm{s})$ & $k\left(\right.$ Pa.s $\left.^{n}\right)$ & $n$ \\
\hline \multirow{4}{*}{ Control } & 3 & 8.3948 & 472.51 & 0.1248 \\
\hline & 5 & 8.4175 & 472.26 & 0.1255 \\
\hline & 7 & 8.7561 & 504.79 & 0.1196 \\
\hline & 9 & 8.5395 & 523.64 & 0.1062 \\
\hline \multirow{4}{*}{ Treated } & 3 & 8.3536 & 467.6 & 0.126 \\
\hline & 5 & 8.6943 & 493.69 & 0.1228 \\
\hline & 7 & 8.9355 & 528.59 & 0.114 \\
\hline & 9 & 8.9943 & 548.74 & 0.1073 \\
\hline
\end{tabular}

${ }_{\mathrm{a}}, 100$ indicates apparent viscosity; $\mathrm{k}$ is consistency index; $\mathrm{n}$ is flow behavior index; 
Table 6. The Power law values of different types of mucilage at different temperatures

\begin{tabular}{ccccc}
\hline Type of sample & Temperature $\left({ }^{\circ} \mathrm{C}\right)$ & $\eta_{\mathrm{a}, 100}(\mathrm{mPa} \cdot \mathrm{s})$ & $k\left(\mathrm{Pa.s}^{n}\right)$ & $n$ \\
\hline \multirow{3}{*}{ Control } & 5 & 8.3948 & 472.51 & 0.1248 \\
& 25 & 8.4175 & 472.26 & 0.1255 \\
& 45 & 8.7561 & 504.79 & 0.1196 \\
\multirow{3}{*}{ Treated } & 65 & 8.5395 & 523.64 & 0.1062 \\
& 5 & 8.3536 & 467.6 & 0.126 \\
& 25 & 8.6943 & 493.69 & 0.1228 \\
& 45 & 8.9355 & 528.59 & 0.114 \\
& 65 & 8.9943 & 548.74 & 0.1073 \\
\hline
\end{tabular}

$\eta_{\mathrm{a}, 100}$ indicates apparent viscosity; $\mathrm{k}$ is consistency index; $\mathrm{n}$ is flow behavior index;

which indicates that high in sucrose contributes to an increase in viscosity (Capitani et al., 2015) due to sucrose promotes hydrogen bonding between the polymer and sugar-OH groups in which sucrose may create junction zones and stabilizing the structure of gel or mucilage. Therefore, the increase in sugar concentration will cause competition between sucrose and mucilage for available water in the food system to form junction zones and promotes more viscous solution (Bayarri et al., 2004) from the mucilage extracted with high temperature $\left(80^{\circ} \mathrm{C}\right)$ and added with high sucrose concentration $(40 \%)$ could increase the viscosity of mucilage solutions.

The effects of different $\mathrm{pH}$ values (3, 5, 7 and 9) on the apparent viscosity of control $\left(25^{\circ} \mathrm{C}\right)$ was compared with treated sample $\left(80^{\circ} \mathrm{C}\right)$ as shown in Table 5. The results showed that changes in $\mathrm{pH}$ had influenced the viscosity of chia mucilage samples when it reached a maximum value of $\mathrm{pH} 5$ and decreased at higher $\mathrm{pH}$ values. For both control and treated mucilage, the lowest viscosity obtained at $\mathrm{pH} 3(9.1700$ and 9.0631$) \mathrm{mPa} \cdot \mathrm{s}$ while the highest value of viscosity was found at $\mathrm{pH} 5$ (9.2887 and 9.2244) $\mathrm{mPa} \cdot \mathrm{s}$, respectively. It shows that changes in $\mathrm{pH}$ towards alkali (pH 5 to $\mathrm{pH} 9$ ) influenced the decreased in apparent viscosity of chia mucilage. It also can be explained that the flow behavior value of $\mathrm{pH}$ 5 is lower than $\mathrm{pH} 7$, which indicates that $\mathrm{pH} 5$ is more viscous than the $\mathrm{pH}$ towards the alkali. In the acidic condition, the apparent viscosity for control and treated samples were low which were $9.1700(\mathrm{mPa} \cdot \mathrm{s})$, and $9.0631(\mathrm{mPa} \cdot \mathrm{s})$ due to polysaccharides chains tend to appear in coil state with acids groups in the free acid form at low $\mathrm{pH}$ (Feng et al., 2007). The coils expanded with the increased in $\mathrm{pH}$ at 5 as a result of electrostatic repulsion between functional groups and caused the intermolecular interactions to occur hence contributes to the increase in viscosity. Apart from that, Table 5 shows a decrease in viscosity from $\mathrm{pH} 5$ to 9 caused by the depolymerisation of mucilage under alkali conditions (Achi and Okolo, 2004). Comparing those two types of chia mucilage samples, resulting in higher viscosity of the control sample compared to the treated sample at different $\mathrm{pH}$. This changes caused by the temperature used during extraction where the mucilage extracted at room temperature give high in viscosity when adjusted to low $\mathrm{pH}$. So, this study indicated that the $\mathrm{pH}$ value of 5 was more applicable in food due to its high viscosity and stability when added into food at low $\mathrm{pH}$.

The effect of different temperature on the apparent viscosity of the mucilage solution was compared with control $\left(25^{\circ} \mathrm{C}\right)$ and treated samples $\left(80^{\circ} \mathrm{C}\right)$. Table 6 shows increased in apparent viscosity for control and treated sample as the temperature increased. It also indicates that changes in temperature had affected the viscosity, indicating it as a temperature dependence. The increase in temperature resulted in rising of consistency index, $k$ value of treated mucilage thus indicated that $k$ value was affected by temperature ranges from 5 to $45^{\circ}$ C. The $k$ value reflected the values of the viscosity while flow behavior, $n$ value was opposite to it. This increasing pattern was due to the molecular chains that can form a gel at a higher temperature where new hydrogen bonds formed within the gum/mucilage molecules (TabiloMunizaga et al., 2018). Meanwhile, Table 6 shows that the apparent viscosity of the treated sample was increased simultaneously from $5^{\circ} \mathrm{C}$ and slightly decreased at $65^{\circ} \mathrm{C}$. Reduction in viscosity might be due to the thermal degradations of high molecular weight mucilage during heating (Abbes et al., 2015). Therefore, it will cause a decrease in intermolecular attraction, thus contributes to the reduction of viscosity. The activation energy $(E a)$ is an indicator of molecule movement, as the temperature increase, the liquid flows more quickly due to higher activation energy (Haminiuk et al., 2006). The effect of temperature on viscosity could be described using the Arrhenius equation, and the values of $E a$ and $\mathrm{R}^{2}$ were tabulated in Table 7. Statistical analysis of $E a$ shows a high value of activation energy $(3.184 \mathrm{~kJ} / \mathrm{mol})$

Table 7. Arrhenius equation parameters of apparent viscosity for control and treated sample

\begin{tabular}{ccc}
\hline Types of sample & $\mathrm{Ea}(\mathrm{kJ} / \mathrm{mol})$ & Coefficient determination $\left(\mathrm{R}^{2}\right)$ \\
\hline Control & 0.865 & 0.9508 \\
Treated & 3.184 & 0.7018 \\
\hline
\end{tabular}


Table 8. The Power law values of different types of mucilage at different salt concentrations

\begin{tabular}{|c|c|c|c|c|c|}
\hline Type of Salt & Type of Sample & Salt Concentration & $\eta_{a, 100}(\mathrm{~Pa} \cdot \mathrm{s})$ & $k\left(P a s^{n}\right)$ & $n$ \\
\hline \multirow{12}{*}{$\mathrm{NaCl}$} & \multirow{6}{*}{ Control } & 0 & 8.9531 & 540.47 & 0.1096 \\
\hline & & 0.035 & 8.9369 & 507.91 & 0.1227 \\
\hline & & 0.069 & 8.9821 & 559.99 & 0.1026 \\
\hline & & 0.103 & 8.9302 & 582.72 & 0.0927 \\
\hline & & 0.138 & 8.8574 & 550.94 & 0.1031 \\
\hline & & 0.172 & 8.6865 & 478.9 & 0.1293 \\
\hline & \multirow{6}{*}{ Treated } & 0 & 7.7331 & 349.75 & 0.1723 \\
\hline & & 0.035 & 8.721 & 462.35 & 0.1378 \\
\hline & & 0.069 & 8.7756 & 427.44 & 0.1562 \\
\hline & & 0.103 & 8.9057 & 540.84 & 0.1083 \\
\hline & & 0.138 & 8.9369 & 507.91 & 0.1227 \\
\hline & & 0.172 & 8.9868 & 537.78 & 0.1115 \\
\hline \multirow{12}{*}{$\mathrm{KCl}$} & \multirow{6}{*}{ Control } & 0 & 8.9531 & 540.47 & 0.1096 \\
\hline & & 0.035 & 9.5029 & 616.96 & 0.0912 \\
\hline & & 0.069 & 9.2809 & 681.38 & 0.0671 \\
\hline & & 0.103 & 9.1954 & 653.99 & 0.074 \\
\hline & & 0.138 & 9.1782 & 622.15 & 0.0844 \\
\hline & & 0.172 & 9.0943 & 669.53 & 0.0665 \\
\hline & \multirow{6}{*}{ Treated } & 0 & 7.7331 & 349.75 & 0.1723 \\
\hline & & 0.035 & 9.3575 & 684.48 & 0.0679 \\
\hline & & 0.069 & 9.2598 & 670.81 & 0.07 \\
\hline & & 0.103 & 9.1511 & 662.63 & 0.0701 \\
\hline & & 0.138 & 10.076 & 778.58 & 0.056 \\
\hline & & 0.172 & 9.4183 & 694.34 & 0.0662 \\
\hline \multirow{12}{*}{$\mathrm{MgCl}_{2}$} & \multirow{6}{*}{ Control } & 0 & 8.9531 & 540.47 & 0.1096 \\
\hline & & 0.01 & 9.0037 & 599.82 & 0.0882 \\
\hline & & 0.02 & 9.0663 & 555.69 & 0.1063 \\
\hline & & 0.03 & 9.089 & 590.09 & 0.0938 \\
\hline & & 0.039 & 9.4563 & 640.5 & 0.0846 \\
\hline & & 0.049 & 9.4907 & 650.28 & 0.0821 \\
\hline & \multirow{6}{*}{ Treated } & 0 & 7.7331 & 349.75 & 0.1723 \\
\hline & & 0.01 & 9.2444 & 676.52 & 0.0678 \\
\hline & & 0.02 & 8.8514 & 552.35 & 0.1024 \\
\hline & & 0.03 & 8.8499 & 571.4 & 0.0987 \\
\hline & & 0.039 & 9.2432 & 596.79 & 0.095 \\
\hline & & 0.049 & 9.3605 & 604.92 & 0.0948 \\
\hline \multirow{12}{*}{$\mathrm{CaCl}_{2}$} & \multirow{6}{*}{ Control } & 0 & 8.9531 & 540.47 & 0.1096 \\
\hline & & 0.01 & 9.5652 & 636.64 & 0.0884 \\
\hline & & 0.02 & 9.4805 & 631 & 0.0884 \\
\hline & & 0.03 & 9.1782 & 622.15 & 0.0844 \\
\hline & & 0.039 & 9.6369 & 656.05 & 0.0835 \\
\hline & & 0.049 & 9.7208 & 681.24 & 0.0772 \\
\hline & \multirow{6}{*}{ Treated } & 0 & 7.7331 & 349.75 & 0.1723 \\
\hline & & 0.01 & 8.6191 & 490.75 & 0.1223 \\
\hline & & 0.02 & 8.9207 & 547.52 & 0.106 \\
\hline & & 0.03 & 9.0663 & 555.69 & 0.1063 \\
\hline & & 0.039 & 9.4786 & 609.46 & 0.0959 \\
\hline & & 0.049 & 9.4961 & 618.22 & 0.0932 \\
\hline
\end{tabular}

$\eta_{\mathrm{a}, 100}$ indicates apparent viscosity; $\mathrm{k}$ is consistency index; $\mathrm{n}$ is flow behavior index; 
by a treated sample compared to control $(0.865 \mathrm{~kJ} / \mathrm{mol})$. This result indicated that the viscosity of the treated sample could be changed due to differences in temperature (Feng et al., 2007). However, the apparent viscosity of the solutions treated at different temperatures did not obey the Arrhenius equation as higher in temperature, causes the viscosity to increase.

The rheological data on Table 8 shows the power law which explained the flow behavior of chia mucilage samples $\left(25^{\circ} \mathrm{C}\right.$ for control and $80^{\circ} \mathrm{C}$ for treated) with a high determination of coefficients $\left(\mathrm{R}^{2}\right)$ more than 0.91 . The data illustrated shear thinning behavior because the values of flow behavior index $(n)$ were less than 1 for all concentrations. The effect of different salt concentrations on apparent viscosity was shown in Table 8 . It can seem that the addition of different types of salts contributes to decrease and increase in viscosity with particular salt concentrations. Rheological behavior of chia mucilage was observed by determining the effect of adding different types of salts into control and treated samples (Table 8). It shows that the decrease in apparent viscosity for control is related to the increase of $\mathrm{NaCl}$ concentrations from $0.103 \mathrm{M}$ to $0.172 \mathrm{M}$. This may relate to the increase of association of counter ions with the polymer molecule thus contributes to a reduction in viscosity of the control sample (Mazza and Biliaderis, 1989).

Meanwhile, the apparent viscosity of the treated sample was increased simultaneously from $0.035 \mathrm{M}$ and $0.069 \mathrm{M}$, as stated in Table 8 . The flow behavior index, $n$ was decreased and the value of consistency coefficient, $k$ was increased with the addition of $\mathrm{NaCl}$ in treated sample which indicates the increased in viscosity similar to the study by Behrouzian et al. (2013) on the effect of $\mathrm{NaCl}$ on rheological properties of cress seed (Lepidium sativum) gum. In addition, a decrease in apparent viscosity was measured after the addition of $\mathrm{KCl}$ for both control and treated sample as the concentration increased. This might be due to the addition of positive ion $(\mathrm{K}+)$ on the mucilage solutions which contributes to the reduction in repulsion and molecule expansion. The flow behavior for both samples was also increased which indicates the decreased in viscosity of the samples. It shows that the $\mathrm{KCl}$ salts are unsuitable as a thickening agent in food as it is unable to increase the viscosity of the solutions. On the other hand, results on the effects of addition of $\mathrm{MgCl}_{2}$ did contribute to the increase of apparent viscosity for control and treated chia mucilage with the rise in the concentration of salts as shown in Table 8 . This result indicated that a higher level of salts led to the reduction of viscosity and caused the mucilage solution appeared more viscous. An increase in the salt concentration promoted by the $\mathrm{Mg}^{2+}$ caused the inter- chain interactions between the molecules of mucilage and increased in apparent viscosity (Koocheki et al., 2009). Increase in $\mathrm{CaCl}_{2}$ concentration from $0.01 \mathrm{M}$ to $0.049 \mathrm{M}$ had decreased the apparent viscosity of the solutions due to the presence of a high amount of salts, $\mathrm{Ca}^{2+}$. Therefore, contributes to the development of junction zones which creates three-dimensional networks causing the polymer solution more viscous (Nickerson et al., 2003). This result was also supported by Koocheki et al.(2009) which shows a decrease in apparent viscosity after adding $0.01 \mathrm{M}$ to the solution of Alyssum homolocarpum mucilage. The $\mathrm{CaCl}_{2}$ was more effective to increase the viscosity of mucilage compared to $\mathrm{NaCl}$ at similar concentrations of salts (Hosseini et al., 2017). In conclusion, the presence of $\mathrm{Na}^{+}, \mathrm{Ca}^{2+}$ and $\mathrm{Mg}^{2+}$ salt could increase the viscosity of the solutions. Oliveira et al.(2001) obtained similar results on rheological properties of E. contortisilliquum gum which conveys that the presence of salts containing $\mathrm{Na}^{+}$and $\mathrm{Ca}^{2+}$ able to increase the viscosity of the gum solutions. These types of salts are suitable in food application where alkali substances are used to improve the viscosity of food.

\section{Conclusion}

This study resulted in a higher yield of the treated mucilage, darker in color and lower values of solubility and water holding capacity than control. The incorporation of high sucrose concentration (40\%), acidic condition $(\mathrm{pH} 5)$, high temperature $\left(65^{\circ} \mathrm{C}\right), \mathrm{NaCl}$ salt concentrations $(0.103 \mathrm{M})$ and $\mathrm{MgCl}$ and $\mathrm{CaCl}_{2}$ salts concentration $(0.049 \mathrm{M})$ contributed to highly viscous of the chia mucilage solutions. It demonstrates that chia mucilage treated at $80^{\circ} \mathrm{C}$ resulted in higher viscosity than the control sample when subjected to different processing conditions.

\section{Conflict of Interest}

The authors declare no conflict of interest.

\section{Acknowledgments}

The authors would like to express their gratitude to Universiti Putra Malaysia (Project number GPIPS/2017/9537200 and GP/2018/9643600) for financial and technical support and Curtin University, Australia for supplying black chia seed to researchers.

\section{References}

Abbes, F., Masmoudi, M., Kchaou, W., Danthine, S., Blecker, C., Attia, H. and Besbes, S. (2015). Effect of enzymatic treatment on rheological properties, glass temperature transition and microstructure of date syrup. LWT-Food Science Technology, 60(1), 
339-345. https://doi.org/10.1016/j.lwt.2014.08.027

Achi, O.K. and Okolo, N.I. (2004). The chemical composition and some physical properties of a water -soluble gum from Prosopis africana seeds. Journal of Food Science and Technology, 39(4), 431-436. https://doi.org/10.1111/j.1365-2621.2004.00801.x

Amid, B.T., Mirhosseini, H. and Kostadinović, S. (2012). Chemical composition and molecular structure of polysaccharide-protein biopolymer from Durio zibethinus seed: Extraction and purification process. Chemistry Central Journal, 6(1),117-131. https://doi.org/10.1186/1752-153X-6-117

Association of Official Analytical Chemists (AOAC) (2000). Official Methods of Analysis of AOAC International. $17^{\text {th }}$ ed. Gaithersburg, MD, USA: AOAC International.

Ayerza, R. (2005). Seed composition of two chia (Salvia hispanica L.) genotypes which differ in seed color. Emirates Journal of Food and Agriculture, 25(7), 495-500. https://doi.org/10.9755/ejfa.v25i7.13569

Bayarri, S., Duran, L. and Costell, E. (2004). Influence of sweeteners on the viscoelasticity of hydrocolloids gelled systems. Food Hydrocolloid, 18(4), 611-619. https://doi.org/10.1016/j.foodhyd.2003.10.004

Behrouzian, F., Razavi, S.M. and Karazhiyan, H. (2013). The effect of $\mathrm{pH}$, salts and sugars on the rheological properties of cress seed (Lepidium sativum) gum. International Journal of Food Science and Technology, 48(12), 2506-2513. https:// doi.org/10.1111/ijfs. 12242

Borneo, R., Aguirre, A. and León, A.E. (2010). Chia (Salvia hispanica L.) gel can be used as egg or oil replacer in cake formulations. Journal of the American Dietetic Association, 110(6), 946-949. https://doi.org/10.1016/j.jada.2010.03.011

Campos, B. Ruivo, E.T.D., da Silva Scapim, M.R., Madrona, G.S. and Bergamasco, R.D.C (2016). Optimization of the mucilage extraction process from chia seeds and application in ice cream as a stabilizer and emulsifier. LWT-Food Science Technology, 65, 874-883. https://doi.org/10.1016/ j.lwt.2015.09.021

Capitani, M.I., Nolasco, S.M. and Tomás, M.C. (2013). Effect of mucilage extraction on the functional properties of Chia meals. In Innocenzo, M. (Eds). Food Industry, p. 421-438. Rijeka, Crotia: Intech.

Capitani, M.I., Corzo-Rios, L.J., Chel-Guerrero, L.A., Betancur-Ancona, D.A., Nolasco, S.M. and Tomás, M.C. (2015). Rheological properties of aqueous dispersions of chia (Salvia hispanica L.) mucilage. Journal of Food Engineering, 149, 70-77. https:// doi.org/10.1016/j.jfoodeng.2014.09.043

de Souza, F.C., de Sousa, F.L.D., Espirito, S.D.S.G. and Rosa G. (2015). Effect of chia seed (Salvia hispanica
L.) consumption on cardiovascular risk factors in humans: a systematic review. Nutricion hospitalaria, 32(5), 1909-1918.

Dick, M., Costa, T.M.H., Gomaa, A., Subirade, M., Rios, A.D.O. and Flôres, S.H. (2015). Edible film production from chia seed mucilage: Effect of glycerol concentration on its physicochemical and mechanical properties. Carbohydrate Polymer, 130, 198-205.

j.carbpol.2015.05.040

https://doi.org/10.1016/

Doublier, J.L. and Cuvelier, G. (2017). Gums and hydrocolloids: Functional aspects. In Eliasson, A-C (Eds). Carbohydrates in food., p. 233-272. New York: Taylor and Francis Group. https:// doi.org/10.1201/9781420015058.ch7

Feng, T., Gu, Z.B. and Jin, Z.Y. (2007). Chemical composition and some rheological properties of Mesona Blumes gum. Food Science and Technology International, 13(1), 55-61. https:// doi.org/10.1177/1082013207076100

Fernandes, S.S and de las Mercedes Salas-Mellado, M. (2017). Addition of chia seed mucilage for reduction of fat content in bread and cakes. Food Chemistry, 227, 237-244. https://doi.org/10.1016/ j.foodchem.2017.01.075

Haminiuk, C.W.I., Sierakowski, M-R., Maciel, G.M., Vidal, J.R.M.B., Branco, I.G. and Masson, M.L. (2006). Rheological properties of Butia pulp. International Journal of Food Engineering, 2(1),1217. https://doi.org/10.2202/1556-3758.1039

Hosseini, E., Mozafari, H.R., Hojjatoleslamy, M. and Rousta, E. (2017). Influence of temperature, $\mathrm{pH}$ and salts on rheological properties of bitter almond gum. Food Science and Technology (Campinas), 37(3), 437-43. https://doi.org/10.1590/1678-457x.18116

Hosseini-Parvar, S., Matia-Merino, L., Goh, K., Razavi, S. and Mortazavi, S. (2010). Steady shear flow behavior of gum extracted from Ocimum basilicum L. seed: Effect of concentration and temperature. Journal of Food Engineering, 101(3), 236-243. https://doi.org/10.1016/j.jfoodeng.2010.06.025

Hulse, J. (1996). Flavour, spices and edible gums: opportunities for integrated agroforestry systems, presented at International Conference on Domestication and Commercialization of Nontimber Forest Products in Agroforestry Systems, Nairobi, Kenya, 1996. Nairobi, Kenya.

Ixtaina, V.Y., Martínez, M.L., Spotorno, V., Mateo, C.M., Maestri, D.M., Diehl, B.W. and Tomás, M.C. (2011). Characterization of chia seed oils obtained by pressing and solvent extraction. Journal of Food Composition and Analysis, 24(2),166-174. https:// doi.org/10.1016/j.jfca.2010.08.006

Kilor, V. and Bramhe, N.N. (2014). Development of 
effective extraction method for Lepidium sativum seed mucilage with higher yield. Journal of Advanced Pharmacy Education and Research, 4(3), 354-360.

Koocheki, A., Mortazavi, S.A., Shahidi, F., Razavi, S.M.A. and Taherian, A.R. (2009). Rheological properties of mucilage extracted from Alyssum homolocarpum seed as a new source of a thickening agent. Journal of Food Engineering, 91(3), 490-496. https://doi.org/10.1016/j.jfoodeng.2008.09.028

Korir, P., Salim, C.A.M., Odalo, J.O.,Waudo, W., Gitu, L.M. and Yusuf, A.O. (2018). Optimization of extraction condition and characterization of Malva verticillata root bark mucilage. International Journal of Chemistry, 10(2), 1-9. https://doi.org/10.5539/ ijc.v10n2p1

Lin, K.Y., Daniel, J.R. and Whistler, R.L. (1994). Structure of chia seed polysaccharide exudate. Carbohydrate Polymer, 23(1), 13-18. https:// doi.org/10.1016/0144-8617(94)90085-X

Mazza, G. and Biliaderis, C.G. (1989). Functional properties of flaxseed mucilage. Journal of Food Science, 54(5), 1302-1305. https:// doi.org/10.1016/0144-8617(94)90085-X

Menga, V., Amato, M., Phillips, T.D., Angelino, D., Morreale, F. and Fares, C. (2017). Gluten-free pasta incorporating chia (Salvia hispanica L.) as thickening agent: An approach to naturally improve the nutritional profile and the in vitro carbohydrate digestibility. Food Chemistry, 221, 1954-1961. https://doi.org/10.1016/j.foodchem.2016.11.151

Muñoz, L.A., Cobos, A., Diaz, O. and Aguilera, J.M. (2012). Chia seeds: Microstructure, mucilage extraction, and hydration. Journal of Food Engineering, 108(1), 216-24. https:// doi.org/10.1016/j.jfoodeng.2011.06.037

Nickerson, M.T., Paulson, A.T. and Speers, R.A. (2003). Rheological properties of gellan solutions: Effect of calcium ions and temperature on pre-gel formation. Food Hydrocolloid, 17(5), 577-83. https:// doi.org/10.1016/S0268-005X(02)00075-9

Noorlaila, A., Siti Aziah, A., Asmeda, R. and Norizzah, A.R. (2015). Emulsifying properties of extracted Okra (Abelmoschus esculentus L.) mucilage of different maturity index and its application in coconut milk emulsion. International Food of Research Journal, 22(2), 782-787.

Oliveira, J.D., Silva, D.A., Paula, R.C.M., Feitosa, J.P.A. and Paula, H.C.B. (2001). Composition and effect of salt on rheological and gelation properties of Enterolobium contortisilliquum gum exudate. International Journal of Biological Macromolecules, 29(1), 35-44. https://doi.org/10.1016/S0141-8130 (01)00151-9
Porras-Loaiza, P., Jiménez-Munguía, M.T., SosaMorales, M.E., Palou, E. and López-Malo, A. (2014). Physical properties, chemical characterization and fatty acid composition of Mexican chia (Salvia hispanica L.) seeds. International Journal of Food Science and Technology, 49(2), 571-577. https://doi.org/10.1111/ ijfs. 12339

Qian, K., Cui, Y.S.W., Wu, Y. and Goff, H.D. (2012). Flaxseed gum from flaxseed hulls: Extraction, fractionation, and characterization. Food Hydrocolloid, 28(2), 275-283. https:// doi.org/10.1016/j.foodhyd.2011.12.019

Reyes-Caudillo, E., Tecante, A. and Valdivia-López, M.A. (2008). Dietary fiber content and antioxidant activity of phenolic compounds present in Mexican chia (Salvia hispanica L.) seeds. Food Chemistry, 107(2), 656-663. https://doi.org/10.1016/ j.foodchem.2007.08.062

Segura-Campos, M.R., Ciau-Solís, N., Rosado-Rubio, G., Chel-Guerrero, L. and Betancur Ancona, D. (2014). Chemical and functional properties of chia seed (Salvia hispanica L.) gum. International Journal of Food Science, 2014, 1-5. https:// doi.org/10.1155/2014/241053

Sengül, M., Ertugay, M.F. and Sengül, M. (2005). Rheological, physical and chemical characteristics of mulberry pekmez. Food Control, 16(1), 73-76. https://doi.org/10.1016/j.foodcont.2003.11.010

Tabilo-Munizaga, G., Sáenz-Hernández, C. and HerreraLavados, C. (2018). Influence of temperature, calcium and sucrose concentration on viscoelastic properties of Prosopis chilensis seed gum and nopal mucilage dispersions. International Journal of Food Science and Technology, 53(7), 1781-1788. https:// doi.org/10.1111/ijfs.13766

Timilsena, Y.P., Adhikari, R., Kasapis, S. and Adhikari, B. (2015). Physicochemical, thermal and rheological characteristics of a novel mucilage from chia seed (Salvia hispanica), presented at Proceedings of the 18th Gums and Stabilisers for the Food Industry Conference. United Kingdom: Wrexham Glyndwr University.

United States Department of Agriculture (USDA) (2011). National Nutrient Database for Standard Reference, Release 24.. Retrieved on April 2018 from USDA website: https://ndb.nal.usda.gov/ndb/ foods/show/12006

Zeng, W.W. and Lai, L.S. (2014). Characterization of the mucilage isolated from the edible fronds of bird's nest fern (Asplenium australasicum). Food Hydrocolloid, 40, 163-172. https://doi.org/10.1016/ j.foodhyd.2014.02.008 